\title{
Dymorfizm płciowy i asymetria wskaźnika długości palców ręki (2D:4D) - badania pilotażowe
}

\section{Sexual dimorphism and asymmetry of digit ratio (2D:4D) - pilot study}

\author{
Katarzyna Zaleska1', Katarzyna Kliś1, Agnieszka Suder², Iwona Teul³, Iwona Wronka \\ ${ }^{1}$ Zakład Antropologii Instytutu Zoologii Uniwersytetu Jagiellońskiego w Krakowie \\ ul. Gronostajowa 9, 30-387 Kraków \\ Kierownik: dr hab. Henryk Głab
}

2 Zakład Anatomii Akademii Wychowania Fizycznego w Krakowie

al. Jana Pawła II 78, 31-571 Kraków

Kierownik: dr hab. Agnieszka Suder

${ }^{3}$ Katedra i Zakład Anatomii Prawidłowej i Topograficznej Pomorskiego Uniwersytetu Medycznego w Szczecinie

al. Powstańców Wlkp. 72, 70-111 Szczecin

Kierownik: dr hab. n. med. Zbigniew Ziętek

\begin{abstract}
Introduction: Numerous studies have demonstrated sexual dimorphism in 2D:4D digit ratio. Shall be regarded that the value of the 2D:4D ratio is determined in fetal life by the action of hormones.

The aim of the study was to evaluate asymmetry and sexual dimorphism in 2D:4D digit ratio.

Material and methods: The study was conducted on a group of 115 women and 46 men, aged 19-25 years. Individuals, which were included in the study, are students of two universities in
\end{abstract}

Cracow - Academy of Physical Education and the Jagiellonian University. The measurement of the length the fingers II and IV both hands was made in each person and the value of digit ratio was calculated for all obtained data.

Results: The women had the higher value of the index 2D:4D in both hands, compared with men covered by the survey. In males it was demonstrated higher average value of the length of the finger IV than the finger II.

Keywords: the length of the fingers, digit ratio 2D:4D, asymmetry, sexual dimorphism.

\section{STRESZCZENIE}

Wstęp: Liczne badania wykazały, że wskaźnik długości palców 2D:4D charakteryzuje się zróżnicowaniem dymorficznym. Uznaje się, że wartość wskaźnika 2D:4D ustala się już w życiu płodowym pod wpływem działania hormonów płciowych.

Celem pracy była ocena asymetrii oraz zróżnicowania dymorficznego wskaźnika długości palców.

Materiał i metody: Przeprowadzono badania na grupie 115 kobiet i 46 mężczyzn w wieku 19-25 lat. Objęte badaniem osoby to studenci dwóch krakowskich uczelni - Akademii Wychowania Fizycznego oraz Uniwersytetu Jagiellońskiego. Na podstawie uzyskanych pomiarów obliczono wartości wskaźnika długości palców. Wyniki: Badane kobiety charakteryzowała wyższa wartość wskaźnika 2D:4D w porównaniu z objętymi badaniami mężczyznami. U mężczyzn wykazano średnio wyższe wartości długości palca IV od palca II.

Słowa kluczowe: długość palców, wskaźnik 2D:4D, asymetria, dymorfizm płciowy.

\section{WSTĘP}

Stosunek długości palca drugiego (2D) ręki do długości palca czwartego (4D) to tzw. indeks długości palców (digit ratio 2D:4D). Wskaźnik ten wykazuje duże zróżnicowanie dymorficzne. U mężczyzn zaobserwowano niższe wartości wskaźnika (2D:4D digit ratio) niż u kobiet [1, 2].

Uważa się, że stosunek długości palca wskazującego do palca serdecznego ustala się u osobnika już w okresie prenatalnym i pozostaje stały przez resztę etapów ontogenetycznych. Wpływ na ten efekt mają mieć działające już w okresie płodowym hormony płciowe, jak np. testosteron lub estrogeny [3, 4, 5]. Manning i wsp. [6] sugerują, że stosunek
2D:4D może zatem odzwierciedlać funkcjonalność gonad i ich czynności, takich jak np. produkcja hormonów. Można zatem doszukiwać się korelacji niskich lub zbyt wysokich poziomów hormonów płciowych u osobnika, co za tym idzie płodności lub bezpłodności związanej z indeksem długości palców [6].

Jak dowodzą wyniki licznych badań, wskaźnik ten przyjmuje różne wartości, w zależności od strony ciała [7]. Asymetria związana z różnicą w długości 2D:4D jest zazwyczaj większa po prawej stronie ciała [7].

Stwierdzono także, że wskaźnik długości palców jest skorelowany z atrakcyjnością biologiczną oraz sukcesem reprodukcyjnym [2]. Badania prowadzone na populacjach europejskich (m.in. Anglia, Hiszpania, Niemcy, Węgry, Polska) oraz 
Jamajki pokazały, że kobiety zamężne cechuje większa wartość 2D:4D niż u kobiet niezamężnych. Ponadto, analizując korelację wskaźnika z sukcesem reprodukcyjnym, udowodniono, że istnieje negatywna zależność 2D:4D u mężczyzn i pozytywna u kobiet. Zauważono również korelację wskaźnika 2D:4D z innymi wskaźnikami. Za przykład może posłużyć wskaźnik talia-biodra (waist-hip ratio - WHR), oznaczający stosunek talii do bioder. Wskaźnik ten, podobnie jak 2D:4D digit ratio, jest zależny od działania testosteronu i estrogenów. Zatem kobiety z niską wartością WHR cechują się niskim poziomem męskich i wysokim poziomem żeńskich hormonów płciowych [8]. Stężenie tych hormonów u matki jest skorelowane z rozwojem płodu. U kobiet z niskim WHR będzie rozwijać się potomstwo charakteryzujące się z wysokim 2D:4D i odwrotnie [8].

Dodatkowo dyskutuje się nad powiązaniem agresji ze wskaźnikiem długości palców. Hönekopp i Watson prowadzili badania, w których wykazano negatywną relację pomiędzy agresją a wielkością 2D:4D, jednak nie wykazano takiej zależności u kobiet [9]. Z kolei w innych badaniach Cleveland udowodniła, że długotrwałe działanie androgenów w okresie prenatalnym jest związane również z agresją występującą u osobników płci żeńskiej [10].

We wszystkich wymienionych publikacjach autorzy podkreślają znaczenie hormonów płciowych w okresie prenatalnym życia osobnika jako głównego czynnika kształtującego różnice w długości palców. Dlatego wskaźnik długości palców ręki 2D:4D, zarówno u kobiet, jak i mężczyzn, ze względu na silną korelację z poziomem hormonów w okresie płodowym oraz zachorowalnością na różne choroby somatyczne i psychiczne może służyć jako wskaźnik ryzyka wystąpienia niektórych chorób oraz jako wskaźnik atrakcyjności czy ogólnej kondycji biologicznej [11].

Celem pracy była ocena zróżnicowania dymorficznego oraz asymetrii wskaźnika 2D:4D.

\section{MATERIA $~ I$ METODY}

Zbadano 115 kobiet i 46 mężczyzn w wieku 19-25 lat. Badane osoby to studenci dwóch krakowskich uczelni: Uniwersytetu Jagiellońskiego oraz Akademii Wychowania Fizycznego. U każdej z osób za pomocą elektronicznego suwaka liniowego dokonano pomiaru długości drugiego i czwartego palca prawej i lewej dłoni. Palce mierzono od punktu da (dactylion) do pph (pseudophalangion). Punkt dactylion znajduje się na końcu palca, punkt pseudophalangion na bruździe nasady palca. Pomiary wykonuje na wyprostowanej ręce, którą badany kładzie stroną grzbietową na stole. Palce ręki podczas pomiaru są złączone [12]. Następnie obliczono wskaźniki 2D:4D dla prawej i lewej ręki.

Za pomocą programu Statistica, w analizie statystycznej obliczono podstawowe charakterystyki, tj. średnią, medianę, odchylenie standardowe oraz wartość maksymalną i minimalną. Normalność rozkładu testowano za pomocą testu Shapiro-Wilka. Ponieważ rozkład danych nie odbiegał od rozkładu normalnego, istotność różnic pomiędzy grupami określono za pomocą testu t-Studenta.

\section{WYNIKI}

W tabeli 1 przedstawiono wyniki dotyczące wskaźnika długości palców oraz dane wyjściowe, które posłużyły do obliczenia tego wskaźnika. Zgodnie z wynikami kobiety cechowała wyższa wartość wskaźnika 2D:4D niż mężczyzn (tab. 1). Zarówno w przypadku prawej, jak i lewej ręki dane były istotne statystycznie.

Na rycinie 1 przedstawiono procentowy rozkład wartości dla kobiet i mężczyzn, u których palec 2D był dłuższy (wskaźnik powyżej 1,02), krótszy (wskaźnik <0,98) oraz w przybliżeniu równy w stosunku do palca 4D $(0,98-1,02)$, uwzględniając podział na rękę prawą i lewą. U większości mężczyzn dłuższy jest palec czwarty, natomiast u kobiet drugi. Zaznacza się niewielka różnica w rozkładzie w zależności od strony ciała (ryc. 1).

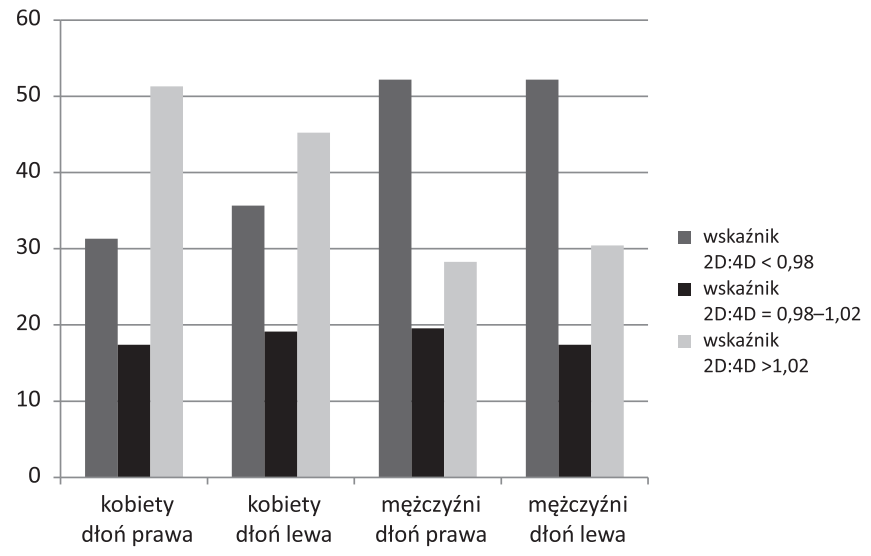

RYCINA 1. Wartość wskaźnika 2D:4D u osób badanych

Sprawdzono, czy różnice w długości palców oraz wskaźnika długości palców u kobiet i mężczyzn w zależności od strony ciała są istotne statystycznie. W dalszej części podano wyniki testu t-Studenta dla obu płci.

U kobiet:

- dla różnicy w długości palca II: $\mathrm{t}=09, \mathrm{p}=0,36$,

- dla różnicy w długości palca IV: $\mathrm{t}=0,23, \mathrm{p}=0,81$,

- dla wskaźnika długości palców: t =0,96, p =0,33.

U mężczyzn:

- dla różnicy w długości palca II: $\mathrm{t}=0,61, \mathrm{p}=0,53$,

- dla różnicy w długości palca IV: $\mathrm{t}=0,42, \mathrm{p}=0,67$,

- dla wskaźnika długości palców: $\mathrm{t}=0,33 ; \mathrm{p}=0,73$.

Na podstawie wyników można stwierdzić, że nie ma znaczących różnic w długości i proporcjach palców w zależności od strony ciała.

\section{DYSKUSJA}

Różnice w proporcjach długości palców ręki w zależności od płci zostały zaobserwowane już w II połowie XIX w. 
TABELA 1. Długość palców [mm] i wskaźnik długości palców w zależności od płci

\begin{tabular}{|c|c|c|c|c|}
\hline \multicolumn{2}{|c|}{ Cecha } & $\begin{array}{l}\text { Kobiety } \\
(n=115)\end{array}$ & $\begin{array}{c}\text { Mężczyźni } \\
(n=46)\end{array}$ & $\begin{array}{c}\text { Wartość testu } \\
\text { t-Studenta }\end{array}$ \\
\hline \multirow{4}{*}{ Długość palca II ręka lewa } & średnia & 67,55 & 72,67 & \multirow{4}{*}{$\begin{array}{l}t=-7,05 \\
p=0,000\end{array}$} \\
\hline & odchylenie standardowe & 4,10 & 4,29 & \\
\hline & mediana & 67,26 & 73,01 & \\
\hline & wartość min-max & $54,69-77,95$ & $62,15-82,14$ & \\
\hline \multirow{4}{*}{ Długość palca IV ręka lewa } & średnia & 67,34 & 73,745 & \multirow{4}{*}{$\begin{array}{l}t=-8,37 \\
p=0,000\end{array}$} \\
\hline & odchylenie standardowe & 4,37 & 4,45 & \\
\hline & mediana & 66,63 & 72,795 & \\
\hline & wartość min-max & $57,05-82,3$ & $65,22-88,37$ & \\
\hline \multirow{3}{*}{ Długość palca II ręka prawa } & średnia & 68,07 & 73,24 & \multirow{3}{*}{$\begin{array}{l}t=-6,63 \\
p=0,000\end{array}$} \\
\hline & odchylenie standardowe & 4,45 & 4,55 & \\
\hline & mediana & 67,95 & 74,0 & \\
\hline \multirow{4}{*}{ Długość palca IV ręka lewa } & średnia & 67,48 & 74,16 & \multirow{4}{*}{$\begin{array}{l}t=-8,06 \\
p=0,000\end{array}$} \\
\hline & odchylenie standardowe & 4,74 & 4,79 & \\
\hline & mediana & 67,09 & 73,47 & \\
\hline & wartość min-max & $55,99-83,23$ & $64,41-85,65$ & \\
\hline \multirow{4}{*}{ Wskaźnik 2D:4D ręka prawa } & średnia & 1,01 & 0,99 & \multirow{4}{*}{$\begin{array}{c}t=2,62 \\
p=0,009\end{array}$} \\
\hline & odchylenie standardowe & 0,047 & 0,046 & \\
\hline & mediana & 1,021 & 0,99 & \\
\hline & wartość min-max & $0,91-1,15$ & $0,87-1,11$ & \\
\hline \multirow{4}{*}{ Wskaźnik 2D:4D ręka lewa } & średnia & 1,00 & 0,99 & \multirow{4}{*}{$\begin{array}{l}t=2,54 \\
p=0,01\end{array}$} \\
\hline & odchylenie standardowe & 0,044 & 0,034 & \\
\hline & mediana & 1,00 & 0,99 & \\
\hline & wartość min-max & $0,84-1,14$ & $0,91-1,048$ & \\
\hline
\end{tabular}

W przeprowadzonych wówczas badaniach osób odmiany białej zamieszkujących Stany Zjednoczone oraz populacji niemieckiej wykazano, że mężczyźni częściej mają dłuższy czwarty palec niż drugi, natomiast kobiety cechuje odwrotna zależność [13]. Liczne badania przeprowadzone w okresie późniejszym potwierdziły tę zależność [2,14, 15]. Uzyskane w ramach prezentowanej pracy wyniki badań również pokrywają się z wynikami prac innych autorów.

Uważa się, że proporcje palców ręki kształtują się we wczesnych etapach życia płodowego na skutek działania hormonów płciowych i w późniejszych etapach życia nie ulegają zmianom $[3,4,5,6]$. Wyniki badań opublikowane w piśmiennictwie dotyczące korelacji stężenia hormonów płciowych w płynie owodniowym z proporcjami palców ręki wykazały jednoznacznie, że przewaga testosteronu nad estrogenami warunkuje męski typ proporcji palców, a przewaga estrogenów nad testosteronem - typ żeński [16]. Wskaźnik długości palców może więc być wykorzystywany jako marker ekspozycji na hormony płciowe w okresie płodowym. Ponieważ wpływ hormonów płciowych na organizm człowieka może mieć bardzo odległe skutki, wiele badań skupia się na zależności pomiędzy wartością wskaźnika 2D:4D a kondycją biologiczną w okresie postnatalnym. Wykazano związek proporcji palców ręki z budową ciała, zdolnościami czy orientacją seksualną [17, 18, 19].

Obecnie wiele prac skupia się na określeniu odległych skutków zaburzeń w rozwoju płodowym. W ten nurt wpisują się także badania nad korelacją wskaźnika długości palców z płodnością, chorobami i nowotworami układu rozrodczego, a także schorzeniami układu krążenia [20, 21]. Innym analizowanym w piśmiennictwie naukowym zagadnieniem jest asymetria proporcji palców dłoni. Większość wyników badań wskazuje na większe różnice pomiędzy długością palca II a IV prawej niż lewej ręki $[9,15,17,20,21]$.

Według wyników w prezentowanej pracy wartość wskaźnika 2D:4D zarówno u kobiet, jak i u mężczyzn nie wykazuje statystycznie istotnych różnic w zależności od strony ciała. Jednak kobiecy typ wskaźnika, w przypadku dłoni prawej, wykazuje $51,3 \%$ badanych kobiet, natomiast dla dłoni lewej tylko 45,22\%. U mężczyzn nie stwierdzono istotnych różnic.

Podsumowując, opracowane $w$ ramach prezentowanej pracy wyniki potwierdzają wykazany przez innych autorów dymorfizm płciowy wskaźnika długości palców 2D:4D. Dane wskazują również na występowanie asymetrii pod względem tej cechy. Mała liczba osób leworęcznych w grupie objętej badaniami nie pozwoliła na testowanie hipotezy, czy asymetria wielkości i proporcji palców dłoni jest związana z lateralizacją. Temat ten zostanie przeanalizowany po zebraniu większej liczby danych.

Wskaźnik długości palców znalazł zastosowanie w bardzo wielu badaniach jako marker odziaływania hormonów w okresie płodowym [22]. Wciąż jednak trwają dyskusję nad zróżnicowaniem etnicznym tego wskaźnika [2, 23]. Prezentowana praca dostarcza nowe dane z terenu Polski, które mogą 
zostać wykorzystane jako dane porównawcze w innych pracach z tego zakresu.

\section{WNIOSKI}

1. W przypadku prawej i lewej ręki kobiety cechowała wyższa niż mężczyzn wartość wskaźnika 2D:4D.

2. U kobiet dłuższy palec czwarty niż drugi w przypadku ręki prawej wykazało 31,3\% badanych, a w przypadku ręki lewej 35,65\%. U mężczyzn wartości te wynosiły w obu przypadkach $52,17 \%$. Dłuższy palec drugi niż czwarty w przypadku ręki prawej u kobiet wykazało $51,3 \%$ badanych, natomiast ręki lewej 45,22\%. U mężczyzn 28,26\% badanych cechował dłuższy palec II niż IV u prawej ręki, natomiast 30,43\% u ręki lewej. Pozostałe osoby miały zbliżone długości obu palców.

\section{PIŚMIENNICTWO}

1. Mularczyk M, Ziętek-Czeszak A, Ziętek Z. Ocena dymorfizmu płciowego wskaźnika długości palców (2D:4D). Ann Acad Med Stetin 2014;60(1):47-51.

2. Manning JT, Barley L, Walton J., Lewis-Jones DI, Trivers RL, Singh D, et al. The 2nd:4th digit ratio, sexual dimorphism, population evidence for sexually antagonistic genes? Evol Hum Behav 2000;21(3):163-83.

3. Rice WR. Evolution of the Y sex chromosome in animals. BioScience 1996;46:331-43.

4. Rice WR. Sexually antagonistic male adaptation triggered by experimental arrest of female evolution. Nature 1996;381:232-4.

5. Rice WR, Holland B: The enemies within: intergenomic conflict, interlocus contest evolution (ICE), and the intraspecific Red Queen. Behav Ecol Sociobiol 1997;41:1-10.

6. Manning JT, Scutt D, Wilson J, Lewis Jones D. The ratio of 2 nd to 4 th digit length: a predictor of sperm numbers and concentrations of testosterone, luteinizing hormone and oestrogen. Hum Reprod 1998;13:3000-4.
7. Jamison CS, Meier RJ, Campbell BC. Dermatoglyphic asymmetry and testosterone levels in normal males. Am J Phys Anthropol 1993;90:185-98.

8. Evans DJ, Hoffmann RG, Kalkhoff RK, Kissebah AH. Relationship of androgenic activity to body fat topography, fat cell morphology, and metabolic aberrations in premenopausal women. J Clin Endocrinol Metab 1983;57(2):304-10

9. Hönekopp J, Watson S. Meta-analysis of digit ratio 2D:4D shows greater sex difference in the right hand. Am J Hum Biol 2010;22(5):619-6.

10. Cleveland ES. Digit ratio, emotional intelligence and parenting styles predict female aggression. Pers Individ Dif 2013;58:9-14.

11. Sluming VA, Manning JT. Second to fourth digit ratio in elite musicians: evidence for musical ability as an honest signal of male fitness. Evol Hum Behav 2000;21:1-9.

12. Malinowski A, Bożiłow W. Podstawy antropometrii. Metody, techniki, normy. Warszawa: Wyd. Nauk. PWN; 1997.

13. Baker F. Anthropological notes on the human hand. Am Anthropol 1888;1:51-76

14. Fink B, Neave N, Manning JT. Second to fourth digit ratio, body mass index, waist-to-hip ratio, and waist-to-chest ratio: their relationships in heterosexual men and women. Ann Hum Biol 2003;30:728-38.

15. McFadden D, Shubel E. Relative lengths of fingers and toes in human males and females. Horm Behav 2002;42:492-500.

16. Lutchmaya S, Baron Cohen S, Raggatt P, Knickmeyer R, Manning JT. 2nd to 4 th digit ratios, fetal testosterone and estradiol. Early Hum Dev 2004;77:23-8.

17. Brown WM, Finn CJ, Cooke BM, Breedlove SM: Differences in finger length ratios between self - identified "butch" and "femme" lesbians. Arch Sex Behav 2002;31:123-7.

18. Manning JT, Pickup LJ. Symmetry and performance in middle distance runners. Int J Sports Med 1998;19:205.

19. Poulin $\mathrm{M}, \mathrm{O}^{\prime}$ Connell RL, Freeman LM. Picture recall skills correlate with 2D:4D ratio in women but not men. Evol Hum Behav 2004;26:174-81.

20. Manning JT. Digit Ratio: a pointer to fertility, behavior, and health. London: Rutgers University Press; 2002.

21. Williams TJ, Pepitone MT, Christensen SE, Cooke BM, Huberman AD, Breedlove NJ, et al. Finger length patterns indicate an influence of fetal androgens on human sexual orientation. Nature 2002;404:455.

22. Putz DA, Gaulin SJC, Sporter RJ, McBurney DH. Sex hormones and finger length What does 2D:4D indicate? Evol Hum Behav 2004;25:182-99.

23. Manning JT, Stewart A, Bundred PE, Trivers RL. Sex and ethnic differences in 2nd to 4th digit ratio of children. Early Hum Develop 2004;80:161-8. 